\title{
ピッチの溶融紡糸における繊維径変動の解析
}

松本光昭, 桶口雅一*, 永田保雄**, 砂子洋文***

\author{
(平成4年3月18日受理)
}

\section{Study on Variation of Filament Diameter during Spining of Pitch Fiber}

\author{
M.Matsumoto, M.Higuchi*, Y.Nagata** and H.Sunago*** \\ New Materials Division, Nippon Steel Corporation; \\ Present address:Three-D Composites Research Corp., 2-1-6 \\ Sengen Tukuba 305, Japan \\ *Advanced Materials \& Technology research Laboratories, \\ Nippon Steel Corporation, 1618 Ida, \\ Nakaharaku, Kawasaki 211, Japan \\ **Product Research \& Development Laboratories, \\ Nippon Steel Chemical Co., 15-1 Shin Minato \\ Kisarazu 292, Japan \\ ***Carbon \& Gas Div., Nippon Steel Chemical Co., \\ 13-16 Ginza 5, Chuoku,Tokyo 104, Japan
}

\begin{abstract}
Short-period variation of filament diameter was measured during melt-spinning of mesophase pitch using Laser-beam scanning diameter-measuring equipment. Filament diameter has been changing continuously owing to change of temperature of atmosphere under the nozzle. Frequency of oscillation of filament diameter was $10 \sim 20 / \mathrm{s}$ for a small disodering of temperature of atmosphere. Coefficient of variation of filament-diameter variation can be reduced when spinning is done in high viscosity or in high spinning velocity. But the low strength of pitch fiber almost limit to select such a mean.
\end{abstract}

KEYWORDS: Carbon fiber, Pitch fiber, Spinning, Pitch, Filanent diameter

\footnotetext{
新日本製鉄(株)新素材事業本部 現所属(株)スリーディコ ンポリサーチ：テ305つくば市千現2-1-6

*新日本製鉄(株)先端技術研究所：テ211 川崎市中原区井田 1618

**現所属 新日鉄化学(株)商品開発センター：干292木更 津方新湊15-1

***現所属 新日鉄化学(株)炭素材ガス本部：テ104 東京都 中央区銀座5-13
}

\section{1. 緒言}

コールタールピッチや石油ピッチを原料とするピッチ系 炭素繊維の製造工程はピッチを織維化する溶融紡系工程, ピッチ纎維を不溶・不融化状態にする不融化工程, それを 炭化して炭素䋐維にする炭化丁程からなっている。なかで も紡系工程は最も重要な工程である。ここではピッチに繊 維としての形状が付与されるとともに、分子の配向が決ま り, 綫維の断面構造が作りこまれる。断面構造の制御はメ ソフェースピッチを原料とする高性能炭素繊維の製造技術 


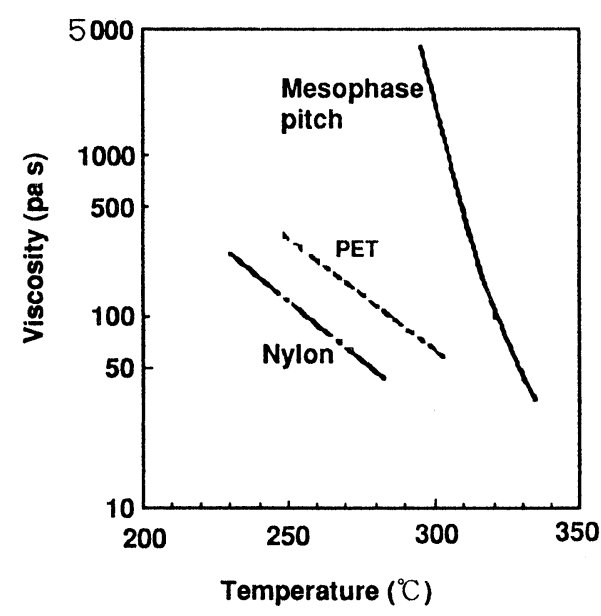

Fig. 1 Viscosity curve of mesophase pitch, comparing with typical polymer

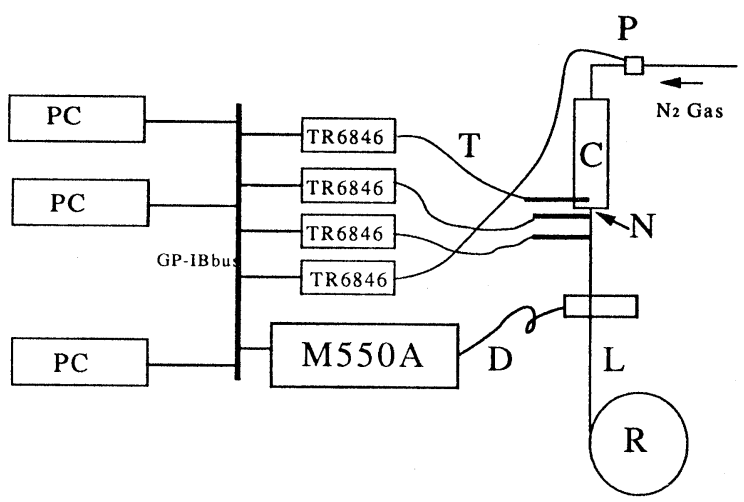

Fig. 2 Schematic diagram of experimental set-up C:molten pitch container N:nozzle R:take-up roller $\mathrm{T}$ :Thermocouple and temperature recorder D:Diameter-sensor by laser and recorder PC:Personal computer P:Pressure sensor and recorder L:Distance between nozzle and take-up roller

上重要な役割を担って扔り，研究報告も出されている12,2) 他方ピッチの細化現象についての研究報告はごく少ない。 小山ら ${ }^{3)}$ は石油ピッチの細化過程の現象を報告している が,ピッチ紡糸中の繊維径の変動や破断などの非定常状態 についての報告は皆無である。

ポリエステルやポリプロピレンなどの合成繊維の溶融紡 糸については, 多くの研究者が紡系の現象論的解析抢よび
紡系の不安定解析の両面から実施している4)-6)。定常状態 の細化過程に関する現象論的解析のモデルは、物質収支， 運動量収支，およびエネルギー収支にもとづくものである から7), 物質の性状が判っていればピッチの溶融紡系にも 適用できると考えられる。他方紡系の不安定解析について は，合成繊維では特にドローレゾナンスにもとづく繊維径 の変動が重視されており，それに関する研究が多い。それ らによると，ドローレゾナンスは，繊維が巻き取り点にお いてなお溶融状態にある場合の現象とされている8)。した がって固化の速いピッチの溶融紡系ではそれにもとづく瀻 維径の変動は生じにくいと考えられる。むしろピッチの場 合は粘度の温度依存性が大きく，また繊維の強度が低いの で, 外乱にもとづく不安定化すなわち繊維径の変動や糸破 断が懸念される。筆者らは単孔紡糸機を用いたメソフェー スピッチの紡糸において，ごく短い周期で繊維径，冷却雲 囲気の温度, ピッチ溶融槽の圧力などを測定し, 繊維径の 変動率と紡糸条件の関係や, 繊維径の変動に及ほす外乱の 影響について研究した。

\section{2. 実験方法およびシミュレーション計算}

\section{1 紡系実験}

紡糸用ピッチは軟化点 $300^{\circ} \mathrm{C}$ のソフェースピッチを 使った。これはFig.1のような粘度特性を持つ。

実験装置はFig.2に示すように単孔紡系機と繊維径測定 装置，温度測定装置，功力測定装置から構成されている。 単孔紡系機はピッチ溶融槽とノズル， $\mathrm{N}_{2}$ によピッチ溶融 槽への加圧装置, リングコーン型巻き取り機からなってい る。この溶融槽にピッチ約 $20 \mathrm{~g}$ をれ $330 \sim 350^{\circ} \mathrm{C} に$ 加熱 し, 直径 $0.3 \mathrm{~mm}$, 長さ $1.2 \mathrm{~mm}$ のキャピラリーを持つノズル かっ $\mathrm{N}_{2}$ 压で押し出し，巻き取り機で巻き取った。織維径の 測定にはアンリツ社製M550A型レーザー式外径測定装置. を用いた。この装置は糸の法線方向にレーザー光を走査 し、レーザー光が繊維で遮られた時間を計測することによ り，繊維の外径を测定する。‥回の測定は0.001sで，16回 の測定の平均を測定值とするように設定した。データの転 送時間を含めた一回の測定に要する時間は0.032sである。 測定位置はノズルの下約 $100 \mathrm{~mm}$ とした。この位置では繊 維は完全に固化が完了しているので, 測定される緎維径は いわゆる紡出繊維の繊維径である。温度測定装置はディジ タル温度計で, 温度センサーは $0.1 \mathrm{~mm} \phi$ JIS K熱電対を用 いた。これをノズル面及びノズル下の，繊維に沿った雲囲 気数簓所に配置した。この熱電対の応答速度は $50^{\circ} \mathrm{C} / \mathrm{s}$ 以上 であった。

ピッチ溶融槽の压力の測定にはトランスデューサー型の 压力センサーを用いた。一回の測定に要する時間はデー夕 のパソコンへの転送時間を含めて0.16sであった。 


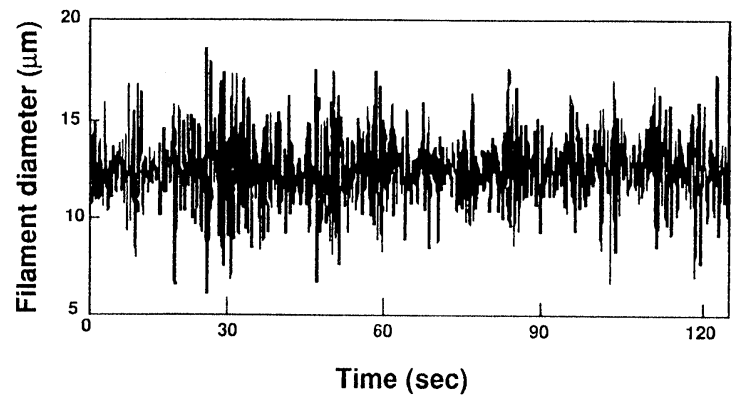

Fig. 3 Record of filament diameter during spinning, where air conditioning is on and $\mathrm{L}=0.46 \mathrm{~m}$.
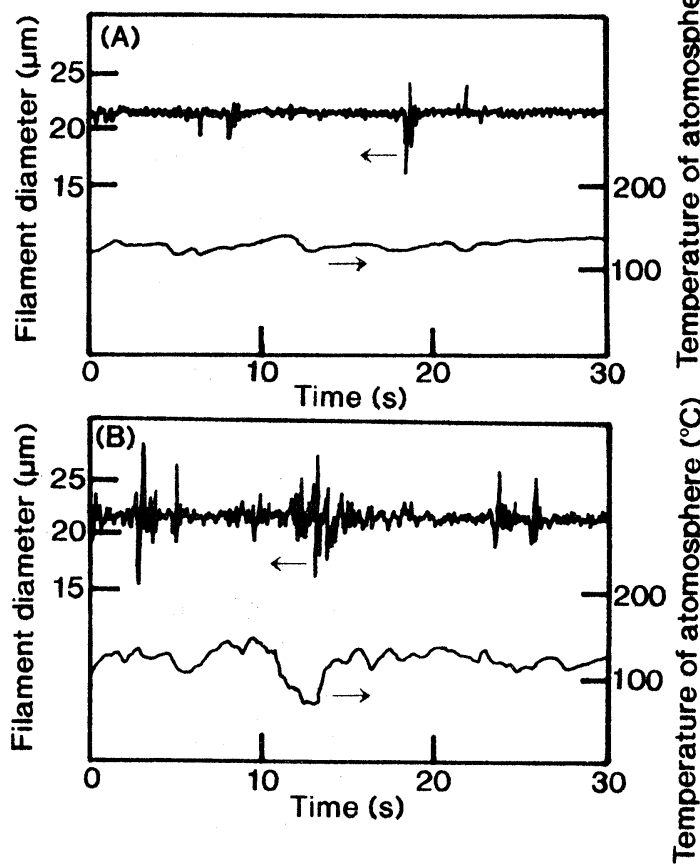

Fig. 4 Records of filament diameter and temperature of atmosphere at $8.5 \mathrm{~mm}$ under the nozzle. Flow rate $=0.044 \mathrm{~g} / \mathrm{min}$. nozzle temp. $=350^{\circ} \mathrm{C}, \mathrm{L}=1.5 \mathrm{~m}$. (A)Air conditioning is off. (B)Air conditioning is on.

各測定装置はGP-IBバスを通じてパソコン $(\mathrm{PC} 98 \mathrm{LT})$ に接 続し、デー夕を記録した。

なお実験は集合空調された建屋の中の室でおこなっ た。

\section{2 紡糸のシミュレーション計算}

ピッチの溶融紡系のシミュレーション算は安田らのモ デル7を使い，ピッチの物性:仙としては实測值からの次の 四帰式を用いておこなった。

$\rho(\mathrm{g} / \mathrm{ml})=1.37-6 \times 10^{-4} \mathrm{~T}$

$C p\left(\mathrm{cal} / \mathrm{g} \cdot{ }^{\circ} \mathrm{C}\right)=0.24+5 \times 10^{-4} \mathrm{~T}$

$\eta(\mathrm{pa} \cdot \mathrm{S})=2.915 \times 10^{-17} \exp \left(2.5 \times 10^{4} / T+273\right)$

ここでT, $\rho, C p, \eta$ はそれぞれ温度 $\left({ }^{\circ} \mathrm{C}\right)$, 密度，比

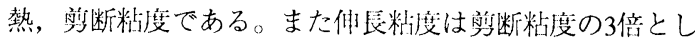
た。

\section{3. 結果と考察}

Fig.3は実験室の空調を連転したままで，約 $12 \mu \mathrm{m}$ の糸を 紡糸した時の緎維径(df)の変動を測った結果である。この

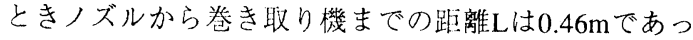
た。Fig.3から判るように䋐維径は大きく変動している。 この実験では紡糸中に，ピッチ溶融槽の圧力と温度を測定 したが，全く変化は無かった。また巻き取り機の回転数を ストロボスコープで測定にしたが，回転むらは無かった。つ ぎにFig.4は距離Lを $1.5 \mathrm{~m} に$ 離し，かつ空調を運転(B)およ び停止(A)の両状態で瀻維徍を测定した結果である。これ にはノズル下 $8.5 \mathrm{~mm}$ の位置で測定した雲囲気温度も示され ている。Fig.3とFig.4(B)を比較するると，実験条件はやや異 なるが，Lの大きいFig.4(B)の方が繊維径の変動が小さい ことが判る。そこで巻き取り機の位置 $\mathrm{L}=1.5 \mathrm{~m}$ と $0.46 \mathrm{~m}$ の両

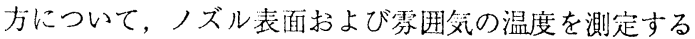
と, Fig.5のような結果となった。この実験では，測定期 間中に巻き取り機を停止，運転，停止と変えている。 $\mathrm{L}=1.5 \mathrm{~m}$ と $0.46 \mathrm{~m}$ を比較すると, $1.5 \mathrm{~m}$ では雲囲気温度の変動 は巻き取り機の運転，停止によってあまり変わらないが，

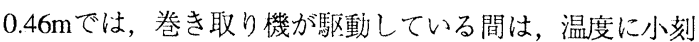
みな振動が入っている。またこのような差は，ノズル表面 温度にも表れている。Fig.5に見るように，ノズル下の緎 維近傍の雲囲気埧度は，ノズル面からの距離 $\mathrm{x}=10 \mathrm{~mm}$ の間

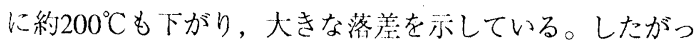
て，この付近の空気が上下方间に移動することは雲囲気温 度に大きな変動をもたらす筈である。これらから，巻き取 り機の回転が周囲の空父に熦らぎを与え，それによって雲 用気温度が採らいで瀻維の冷却条件が変動し，その結果繊 維径が変動するに至ると考えられる。その影響はLが大き いと緩和される。つぎにFig.4の(A)および(B)を比較する と, 空周を運転している(B)の力が雲用氛温度㧍よび瀻維 徍の変動が大きい。空調による室内空気の動きによって， ノズル下の家四気温度が变動し，繊維径が振動すると考え られる。 

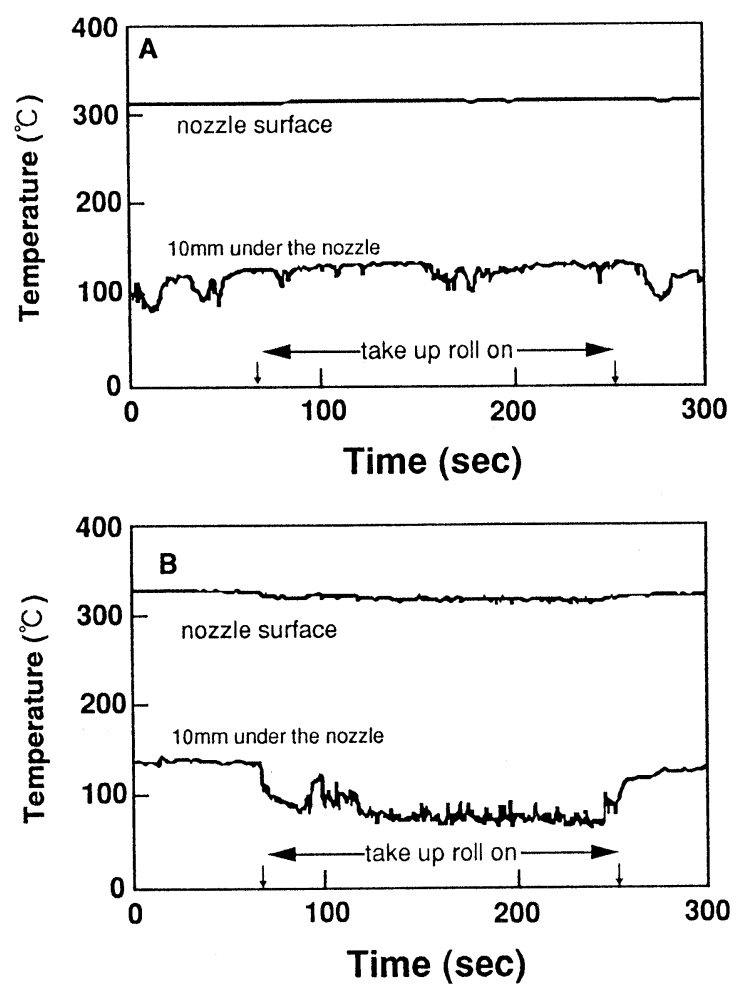

Fig. 5 A comparison of temperatures between two spinning conditions. $\mathrm{A} ; \mathrm{L}=1.5 \mathrm{~m}, \mathrm{~B} ; \mathrm{L}=0.46 \mathrm{~m}$

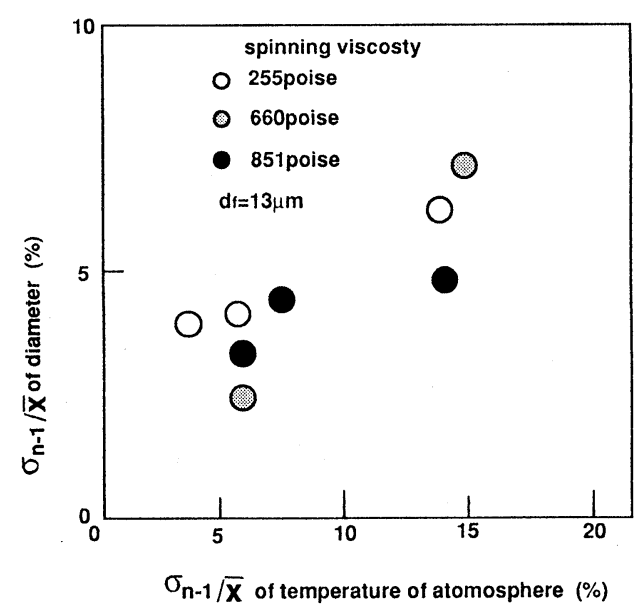

Fig. $6 \sigma_{\mathrm{n}-1} / \overline{\mathrm{X}}$ of filament diameter versus $\sigma_{\mathrm{n}-1} / \overline{\mathrm{X}}$ of atmosphere at $3 \mathrm{~mm}$ under the nozzle $\mathrm{L}=1.5 \mathrm{~m}$.

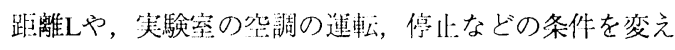

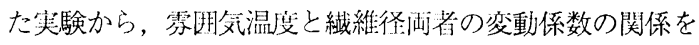
調べるとFig.6のようになった。ここで各プロットは測分 時間123s間における変動を示しており, 繊維徍は4096個, 雲四気温度は886個のデー夕から求めたものである。活者 に強い相関があること, ピッチ溶融槽の压力と温度や巻き 取り機の回転数は安定していることから考え, 緎維徍変動 の原因は打もに雲腯父温度の変動によるものと言うことが できる。このことについてさらに詳しく調べるために， $\mathrm{L}=1.5 \mathrm{~m}$ で, かつ空調の運転の無い, 㚣定した紡系状態の 時に，ノズルに向かって一回ごく軽く風を吹きかけ，温度 と繊維径の動きを観察した。結果はFig.7に示したよう に, 温度の変動はほとんど 1,2 回の振動で収まっているの にたいし，繊維径は大きく振幅し，周期の短い減衰振動を 呈している。振幅が更に大きいと繊維の破断にも慗がるで あろう。

雲囲気温度の影響を見るために，问一引取張力下におけ る3つの冷却条件での紡系中の瀻維径の変化をシミュレー ション計算した。結果をFig.8に示した。Fig.8で，冷却条

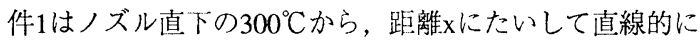

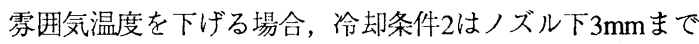
は1と同じパターンで朎却し，そこからは $150^{\circ} \mathrm{Cで}$ 冷却する 場合，冷却条件 3 はノズル下 $2 \mathrm{~mm}$ までは 1 と同じパターン で冷却し，そこからは $150^{\circ} \mathrm{C} て ゙$ 冷却する場合である。Fig. 8 の冷却条件 2 と 3 で比較すると, 冷却雲囲気の温度の変曲 点 $\left(250^{\circ} \mathrm{C}\right.$ 付近から $150^{\circ} \mathrm{C}$ に低下する位置)が, 僅か $1 \mathrm{~mm}$ 変わ るだけで，紡出繊維の繊維径が $14 \mu \mathrm{m}$ から $18 \mu \mathrm{m}$ に大きく 変わっている。このことからノズル直下の雲囲気温度の影 響はきわめて大きいことが判る。Fig.7の織維径の変動現 象をFig.8のシミュレーション結果をもとに考察する。Fig. 8は冷却パターンの差による繊維固化パターンの差の, 静 的な解析モデルである。これにたいLFig.7は，定常的な 紡系状態の途中に瞬間的に外乱(雲囲気温度の低下)が入る 動的な現象であって，Fig.8とは異なるが，つぎのように 推論される。Fig.7の安定した紡系状態の途中で，冷却温 度が急に低下することは，あたかもFig.8の冷却条件1で紡 系していたものが，急に冷却条件2あるいは3に移行するこ とに相当する。このため紡出繊維の繊維径は太くなる方向 に移行する。しかしその直後には，引取速度を保証するた めに(巻き取り速度は変わらないので)元よりも細い部分が できる。そのため吐出口に伝達される張力が下がり，吐出 量とのバランスが崩れて太い部分ができる。これが繰り返 されてFig.7に示したような減衰振動を呈することになる と考えられる。

Kaseら9)は合成瀻維(ポリプロピレン)の紡糸中冷却風を 瞬間的に1\%増やし，それによる繊維径(そこでは繊維の断 


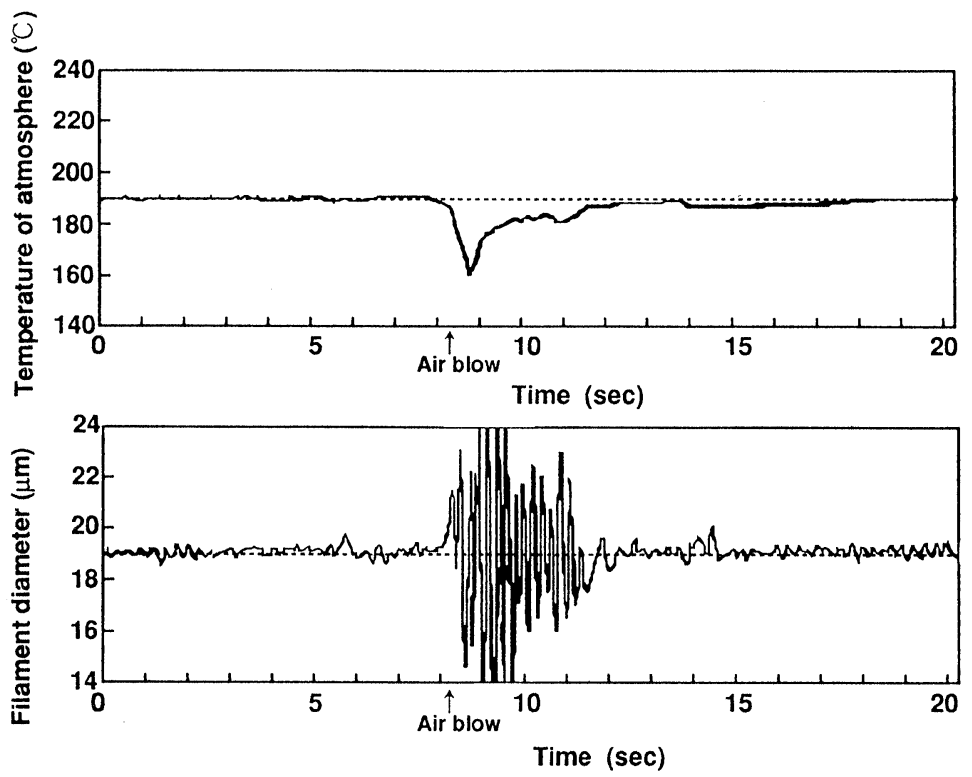

Fig. 7 Vibrations of temperature of atmosphere(A) and filament diameter (B) when a small air blowing was given to the path of filament. Temperature was measured at $3 \mathrm{~mm}$ under the nozzle.
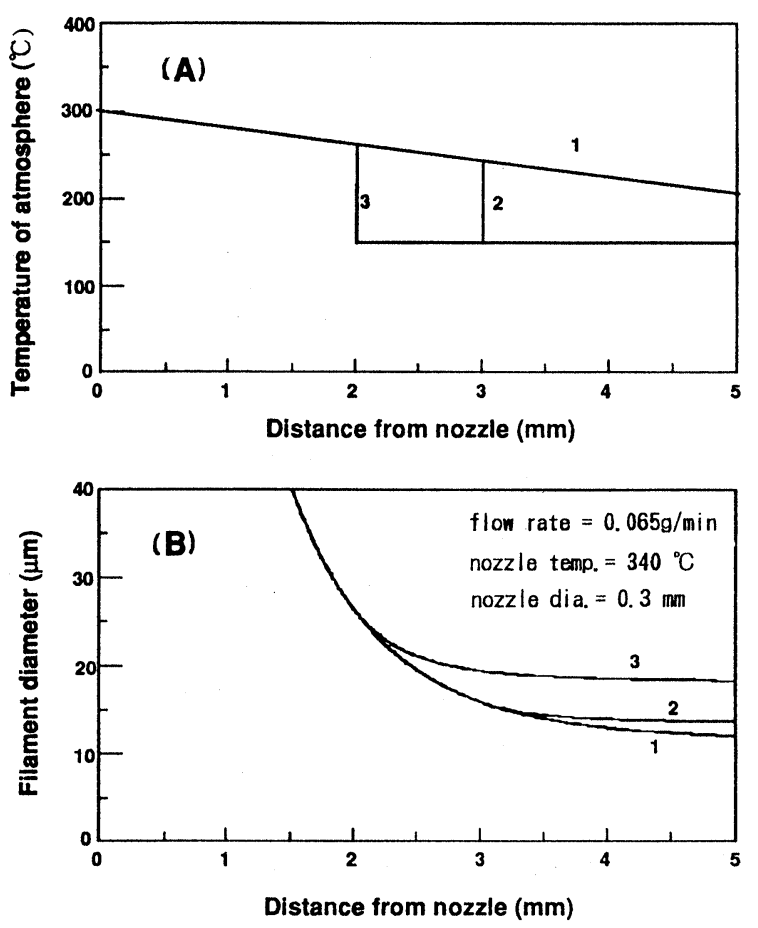

Fig. 8 Filament diameters(B) along the spin line for three cooling conditions(A). (by calculation)
面積)の動きを，シミュレーション計算している。そこで の綫維断面積の振動は 1 サイクル $1.3 \mathrm{~s}$ 程度のゆっくりした 動きであり，振幅も0.4\%程度と小さい。それも2回目には 大幅に減衰している。彼らは，その振動の周期が，ポリ マーがノズルを離れて固化する迄の滞在時間の2倍に相当 することを認めている。ポリプロピレンの場合に較べる と, Fig.7のピッチの振動は振幅と振動数が非常に大き い。Fig.7から繊維径の変動の振動数を読むと，10〜20回 /s程度と読める。Fig.8(冷却条件3)のシミュレーション計算 では，滞在時間は僅か $0.03 \mathrm{~s}$ 程度になるので，Kaseの理論 を適用すると振動周期は0.06sである。すなわち17回/s程度 の振動が生じている。このような激しい繊維径の変動は, ピッチが合成繊維に較べて粘度の温度依存性が高いこと, および(紡糸温度が高いことに起因して)冷却速度が大きい ことの現れであると言える。これらのことからピッチの紡 糸における䨌囲気温度変動の影響はきわめて大きいことが 判る。

つぎに吐出量および粘度を変えて紡糸した時の繊維径の 変化の変動係数 $\left(\sigma_{n-1} / \overline{\mathrm{x}}\right)$ はそれぞれFig.9, Fig.10のように なった。これらから, ある目標の瀻維径に曳く場合, 吐出 量を多くして高速で曳き，また紡糸粘度も高くするほうが 繊維徍の変動率を小さく出来ることが判る。これらはいず れも紡糸張力を高くする方向であり，合成䋐維の溶融紡系 において述べられていることと一致する ${ }^{10)}$ ○こでこのよ うな手段の実行可能性について検討する。 


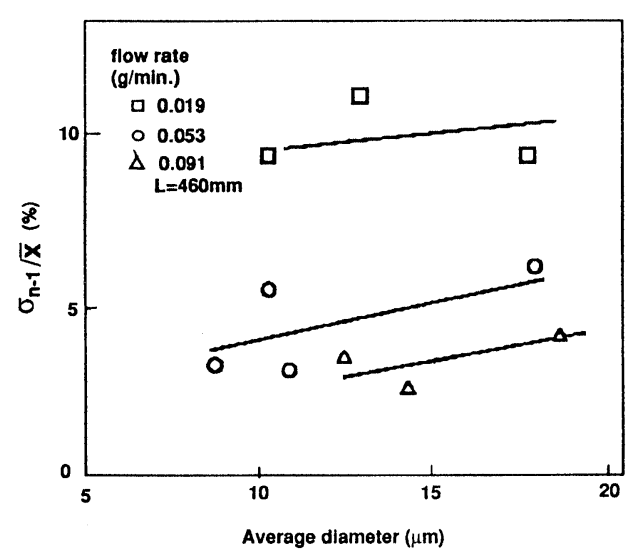

Fig. $9 \sigma_{n-1} / \bar{X}$ versus $\bar{X}$ of filament diameter.

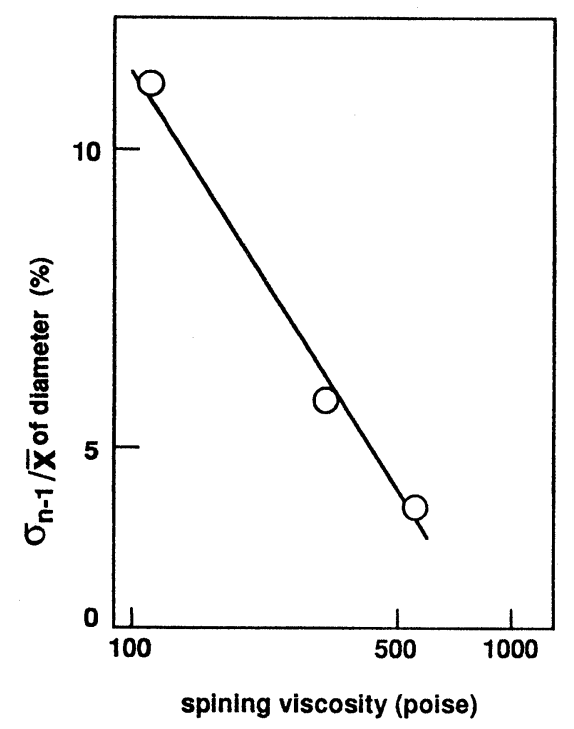

Fig.10 Relation between $\sigma_{\mathrm{n}-1} / \overline{\mathrm{X}}$ of filament diameter and spining viscosity. Flow rate was $0.05 \mathrm{~g} / \mathrm{min}$., average diameter was $18 \mu \mathrm{m}$.

Fig.11は, 繊維にかかる空気抵抗の, ピッチ繊維の引張 強度(実測值50MPa)に対する比率(Fair)を計算したものであ る。ここでLは1.5mであり, 紡糸条件としては, ピッチ吐 出量と巻き取り速度を変えている。工業的な紡系を想定 し，とりうるFairとして0.1程度，すなわち空気抵抗に係わ る安全率を10倍程度と考えると, この図から繊維径 $15 \mu \mathrm{m}$ では $0.2 \mathrm{~g} / \mathrm{min}$ ，また $10 \mu \mathrm{m} て ゙ は 0.05 \mathrm{~g} / \mathrm{min}$ 程度が限界であ る。この結果から吐出量を多くする手段はかなり限られた ものであることがわかる。つぎに紡系粘度(紡糸温度にお

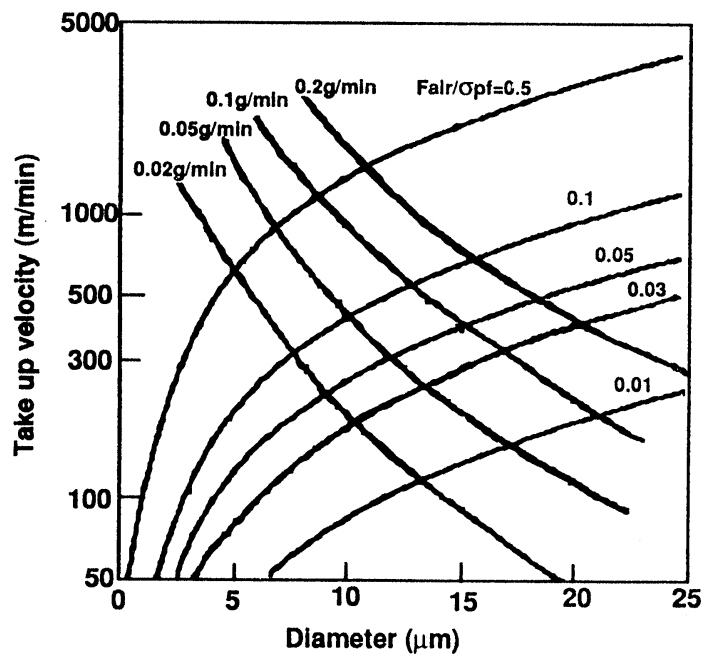

Fig.11 Relation between take up velocity, filament diameter and stress due air friction(Faero) spun at $\mathrm{L}=1.5 \mathrm{~m}$. (by calculation)

Fair: Ratio of Faero to tensile strength of pitch

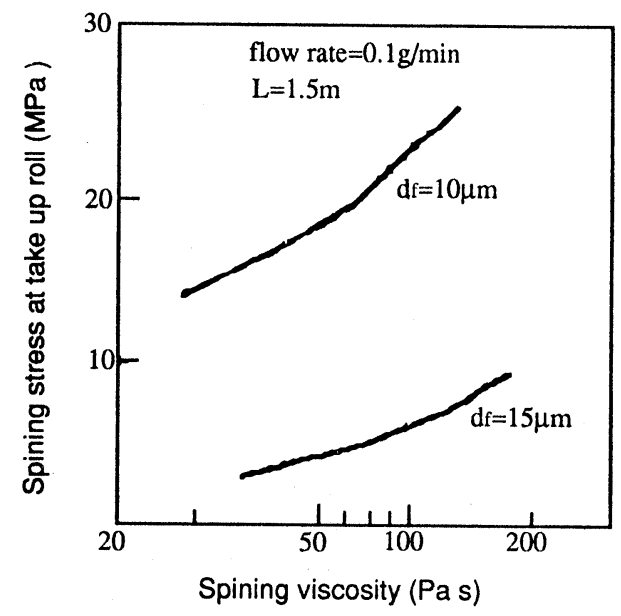

Fig.12 Relation between spinning stress and spining viscosity. (by calculation)

ける剪断粘度)と紡糸張力の関係のシミュレーション計算 の結果はFig.12のようになった。ここで吐出量は $0.1 \mathrm{~g} / \mathrm{min}, \mathrm{L}=1.5 \mathrm{~m}$ でる。このケースを例に考察する。や はり繊維の切断に対する安全性から考えて, 紡糸張力を ピッチ纎維の引張強度の10分の1, すなわち5MPaに抑える

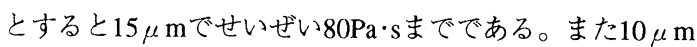
では，この吐出量ではほとんど安定して戋ける温度範囲が 無い。合成繊維例えばナイロンでは，繊維の引張強度は 


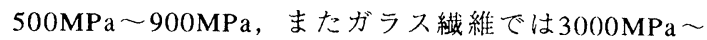
$4000 \mathrm{MPa}$ もるので紡糸粘度をかなり㟧くして操業するこ とができるであろう。しかし強度が極端に低いピッチ瀻維 では，取りうる粘度範囲も限られてくる。このような結果 から考えると, ピッチの紡系においては, 叶出星を多くし たり，紡系粘度を高くするような方法で繊維径の変動摔を 抑えることはかなり難しい。

以上のようなことから繊維径の変動獄を抑えるために は，限られた操業条件のなかで，外乱，とくに宗目攽温度 を乱す要因についての配慮が重琶であることが判る。

\section{4. 結 論}

モノホール紡糸装置に特殊な繊維径測走装置を取り付 け,メソフェースピッチの紡系中の繊維径の变動を細かく 観察した。併せてピッチの紡糸過程をシミュレーション们 算し，その結果つぎのような知見が得られた。

繊維径の変動係数とノズル近傍の雲用気温度の変動係 数とは強い相関関係がある。

ノズル近傍に雲囲気温度変動のショックが入ると繊維 径は激しく変動する。これはピッチの粘度特性と, 高い紡 系温度にもとづく特徴であり振幅と振動数は合成繊維にく らべて非常に大きい。

外乱による繊維径の変動への影響を抑えるために紡系 張力を高くするアクションは，ピッチ繊維が弱いので狭い 範囲でしか適用できない。

\section{謝辞}

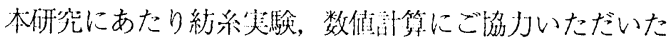

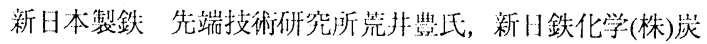
素材技術センター水内和浐巩に媣く感謝の急を表します。

\section{文献}

1) T. Hamada, T. Nishida, Y. Sajiki and M. Matsumoto. J. Mater. Res. 2 (1978) 850-857.

2) D.D. Edie, N.K. Fox and B.C. Barnett, Carbon 24 (1986) 477-482.

3) 小山清人, 青木勝博, 不场 修, 綫維学会誌 44 (1988) 59-63.

4) 石原英炤, 後藤真澄, 安旧 浩, 繊機誌 38 (1985) P-258-267.

5) 石原英昭, 林 清秀, 日本レオロジー学会誌 17 (1989) 19-26.

6) 鳥海浩一郎, 近田淳雄, 繊維学会誌 40 (1984) T-193-201.

7) 安田 浩, 石原英昭, 染川博生, 繊維学会誌 34 (1978) P-20-27.

8) S.Kase, J. Appl. Polym. Sci. 18 (1974) 3279-3304.

9) S.Kase and T.Matsuo, J. Appl. Polym. Sci. 11 (1967) 251-287.

10）安田 浩，杉川博茂，緎維学会誌 37. (1981) T-497 -501 . 